\title{
Social Background and Education of Swedish and Finnish Speakers in Finland
}

\author{
JAN SAARELA \& FJALAR FINNÄS
}

\section{Introduction}

It has been recognised for many years that social background is an important determinant of education (Nam \& Folger, 1965; Sewell \& Hauser, 1975; Hauser \& Sewell, 1986; Corcoran et al., 1976; 1990; Mare, 1979; 1980). ${ }^{1}$ Finland is no exception (Kivinen et al., 1990; Kivinen, 1996; Kivinen \& Rinne, 1996). In 1995, $59 \%$ of 20-24-year-olds with a father having an education above upper secondary level were continuing their studies, as compared to $39 \%$ for those with a father with upper secondary education and $31 \%$ for those with a father with an education below upper secondary level (Haven, 1999, pp. 146-147). This seems to contradict a central objective of the Finnish education policy, which is to provide equal opportunities for all, irrespective of economic situation, gender and mother tongue (Ranta, 1998).

The fourth Finnish school doctrine emphasised equality of educational opportunity, especially with regard to social and regional background (Kivinen, 1988; Lampinen, 1998). In line with these objectives and because of parents' increasing desire to educate their children, the education system was reformed between 1972 and 1977. Previously, compulsory education was provided in seven-year folk schools. After four years of folk school, pupils entered secondary school. Whereas the folk school was totally free of charge, a fee had to be paid by those attending secondary schools. Secondary education was divided into five-year lower and three-year upper secondary school. Success in an upper secondary school examination was, and still is, a prerequisite for entry to university and other tertiary level education. Those who went through the whole (seven-year) folk school could enter certain vocational schools, whereas those with lower secondary education could continue in higher-level vocational schools. Nearly all upper secondary schools and most lower secondary schools were located in cities.

The reform combined the folk school and the lower secondary school into nine-year compulsory education. This had some very important consequences for further education. Compulsory school was made common and free for everyone. Upper secondary (general) schools are now financed by the State and several new ones have been founded in rural areas. School career choice is now postponed. In the previous system, one had to know at age 11 if one was aiming at tertiary level education. In the new system, this choice is not made before the age of 16 .

In the light of this, we want to study whether there are any indications of a diminishing effect of social and regional background on education, especially 
following the reform. Previous research (Mare, 1979) has shown that there are declining background effects from lower to higher education levels. With this in mind, we focus on upper secondary general education and tertiary level education. Those who entered the school system before the reform are compared with those who entered after the reform.

Finland is officially a bilingual country in which Finnish and Swedish speakers are guaranteed equal constitutional rights. Hence, there are two parallel education systems up to upper secondary level, with the same curriculum, but with instruction in each language. There are also schools in several fields at tertiary level for the Swedish-speaking minority. There are more student places for the Swedish speakers than for the Finnish speakers (Statistics Finland, 1993, p. 7). Thanks to these two systems, we can study the impact of background factors on the education propensity of two populations who live in the same area and follow a similar education system.

Swedish speakers have had a higher level of education than Finnish speakers (Finnäs, 2001, p. 59). This could be due to their greater degree of urbanisation at national level and their generally more favourable socio-economic position. So far, very little is known about language-group differences in education propensity. We shall therefore focus on the main settlement area of the Swedish-speaking population in which Finnish speakers also live. We shall use an extract from Statistics Finland's Finnish Longitudinal Census Data File to follow cohorts from their childhood and study individual educational careers.

\section{Data and Methods}

The Finnish Longitudinal Census Data File (Statistics Finland, 1991) contains linked individual information for all residents from the censuses of 1970, 1975, $1980,1985,1990$ and 1995. In addition to the level of education achieved and demographic variables such as year of birth (five-year intervals), gender, and place of residence, we shall also use socio-economic status, type of family and native language.

The longitudinal structure of the data makes it possible to study the effect of conditions in childhood on subsequent behaviour. In order to measure these conditions as closely as possible to the time when the strategic choices for education career were made, we use information at age 10-14. Since economically inactive persons are classified according to the socio-economic position of the head of the household, we have access to information about social background. The other background variables are also measured at this point of time. We approach the problem by constructing a sequence of two dichotomous variables (Mare, 1979; 1980), denoting whether a person has completed upper secondary general education and tertiary level education. The population under study consequently diminishes between upper secondary level and tertiary level education. We model the propensity to have completed education at upper secondary level and tertiary level respectively, using birth cohort and social, family and regional background.

Pupils usually complete upper secondary general education at age 19. This means that, in order to know who has completed education at this level, we must study the conditions at age $20-24$. We measured tertiary level education at age 25-29 so as to be able to include three cohorts (those born between 1956 and 1960, 1961 and 1965 and 1966 and 1970) in the analysis. Parallel analyses for 
tertiary level education at age 30-34 were also carried out, which leaves us with only the two older cohorts. According to the data, which also include cohorts born before 1956, about two-thirds of those with a tertiary level education reached this level before the age of 30. Education at age 30-34 thus provides a somewhat more detailed picture.

We restricted the data to people living in the bilingual part of Finland at age 10-14. This area consists of the 51 officially bilingual ${ }^{2}$ or monolingual Swedish municipalities on the Western and Southern coasts, since nearly all Swedish speakers are concentrated there. ${ }^{3}$

For the regional background variable, we attempted a number of different categorisations. One important aspect is the distinction between urban and rural areas. This is because, before the school reform, almost all upper secondary schools were in cities. Following the reform, people should have had similar possibilities to find upper secondary education, independent of their place of residence.

Originally, we also tried to use a classification according to counties. We could not, however, find any clear indications of between-county differences in education propensity. A regional context is important to separate the most urban areas, with old university traditions (Helsinki and Turku), from the others. We therefore ended up with a distinction between the Helsinki area, the Turku area, other urban areas, and rural areas (see Figure 1).

It should be emphasised that regional background, as well as the other background variables throughout the study refer to conditions at age 10-14 and not to those who had completed their education.

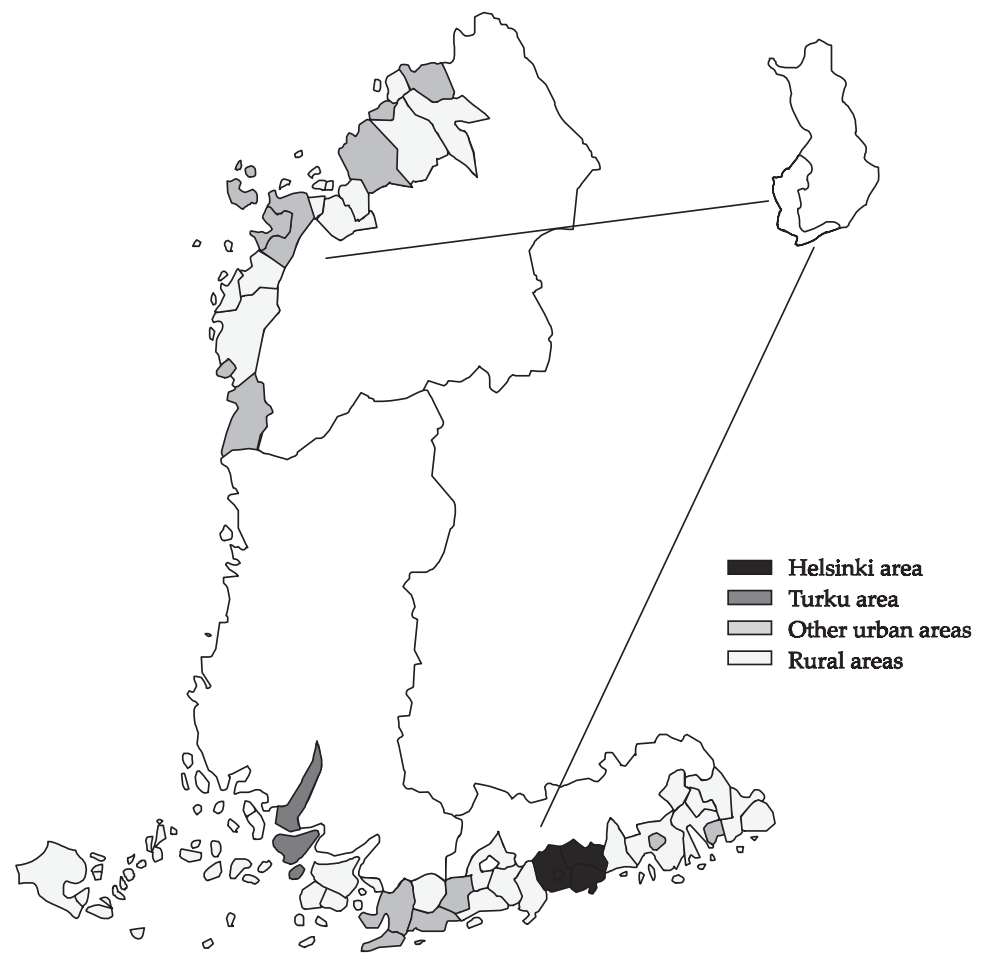

FIGURE 1. Categorisation of the regional background variable 
TABLE I. Distribution of background variables (\%) by native language

\begin{tabular}{lcc}
\hline & Swedish speakers & Finnish speakers \\
\hline Socio-economic background & & \\
Blue-collar worker & 30.0 & 43.4 \\
Lower-level white-collar worker & 20.7 & 24.2 \\
Upper-level white-collar worker & 18.7 & 19.7 \\
Employer & 8.4 & 5.0 \\
Farmer & 16.2 & 1.0 \\
Other & 6.0 & 6.8 \\
Family background & & \\
Two parents & 88.2 & 80.9 \\
One parent & 9.1 & 15.5 \\
No family & 2.7 & 3.6 \\
Regional background & & \\
Helsinki area & 20.3 & 65.1 \\
Turku area & 4.7 & 14.8 \\
Other urban areas & 33.5 & 12.3 \\
Rural areas & 41.6 & 7.8 \\
Birth cohort & & \\
1956-1960 & 33.1 & 31.0 \\
1961-1965 & 33.4 & 34.8 \\
1966-1970 & 33.4 & 34.2 \\
$\mathrm{~N}$ & 53,082 & 199,478 \\
\hline
\end{tabular}

The description is for both genders, since the variable distribution for males is similar to that for females.

Type of family makes a distinction between children who live with both parents, with only one parent and those who do not live in a family. We believe that this affects the education career. Since widows and divorced mothers previously had more difficulties in financing secondary education for their children, the impact of this factor may have led to inter-cohort changes.

Since there are parallel education systems for each language group, Swedish speakers and Finnish speakers are analysed separately. In each case, separate models are also estimated for males and females. This is because the inter-cohort change in education propensity shows a differing pattern for each gender during the period under study (Central Statistical Office of Finland, 1988, p. 5). ${ }^{4}$

Table I shows the distribution of background variables for each language group. As can be seen, the proportion of people from a farmer background is higher among Swedish speakers, whereas the propoportion from blue-collar background is higher among Finnish speakers. In addition, Swedish speakers are more likely to come from two-parent families (Finnäs, 1997). Also, with regard to regional background there are language-group differences. Only 25\% of the Swedish speakers lived in the Helsinki and Turku areas when they were 10-14 years of age, as compared to $80 \%$ of the Finnish speakers.

Table II gives the percentage of people who have completed upper secondary education and tertiary level education at age 25-29 and at age 30-34, conditional on upper secondary education, by cohort, gender and native language. Men are less likely than women to have upper secondary general education. However, of those with upper secondary education, they seem to have continued to tertiary level more frequently than women. 
TABLE II. Percentage of people with completed upper secondary general education and tertiary level education (conditional on upper secondary general education) by birth cohort, gender and native language

\begin{tabular}{|c|c|c|c|c|c|c|}
\hline & \multicolumn{3}{|c|}{ Swedish speakers } & \multicolumn{3}{|c|}{ Finnish speakers } \\
\hline & $\begin{array}{c}\text { Upper } \\
\text { secondary }\end{array}$ & $\begin{array}{r}\text { Tertiary } \\
\text { at } 25-29\end{array}$ & $\begin{array}{l}\text { Tertiary } \\
\text { at } 30-34\end{array}$ & $\begin{array}{c}\text { Upper } \\
\text { secondary }\end{array}$ & $\begin{array}{l}\text { Tertiary } \\
\text { at } 25-29\end{array}$ & $\begin{array}{r}\text { Tertiary } \\
\text { at } 30-34\end{array}$ \\
\hline \multicolumn{7}{|l|}{ MALES } \\
\hline $1956-1960$ & 31.9 & 27.8 & 42.8 & 33.8 & 22.5 & 37.0 \\
\hline 1961-1965 & 36.0 & 25.0 & 42.2 & 38.0 & 17.7 & 32.6 \\
\hline 1966-1970 & 49.7 & 25.3 & n.a. & 48.6 & 19.6 & n.a. \\
\hline Total & 39.1 & 25.9 & 42.5 & 40.3 & 19.7 & 34.6 \\
\hline $\mathrm{n}$ for risk set & 27,288 & 10,675 & 5,760 & 102,114 & 41,146 & 23,684 \\
\hline \multicolumn{7}{|l|}{ FEMALES } \\
\hline 1956-1960 & 43.7 & 24.2 & 33.1 & 43.5 & 18.2 & 28.0 \\
\hline 1961-1965 & 51.1 & 25.1 & 36.9 & 49.3 & 14.4 & 24.8 \\
\hline 1966-1970 & 58.4 & 26.2 & n.a. & 56.1 & 17.9 & n.a. \\
\hline Total & 51.2 & 25.3 & 35.2 & 49.8 & 16.8 & 26.2 \\
\hline $\mathrm{n}$ for risk set & 25,794 & 13,195 & 7,368 & 97,364 & 48,529 & 28,549 \\
\hline
\end{tabular}

Percentage with tertiary level education at age 25-29, not conditional on upper secondary general education, in 1956-1960, 1961-1965 and 1966-1970 cohorts is 8.9, 9.0 and 12.6 for Swedishspeaking males; 7.6, 6.7 and 9.5 for Finnish-speaking males; 10.6, 12.8 and 15.3 for Swedishspeaking females; 7.9, 7.1 and 10.1 for Finnish-speaking females.

Percentage with tertiary level education at age 30-34, not conditional on upper secondary general education, in 1956-1960 and 1961-1965 cohorts is 13.0 and 14.5 for Swedish-speaking males; 12.3 and 12.2 for Finnish-speaking males; 13.8 and 17.9 for Swedish-speaking females; 11.9 and 12.0 for Finnish-speaking females.

The overall proportion of men with upper secondary education has been slightly lower among Swedish speakers than among Finnish speakers. The opposite is true for women. For both genders, the proportion of Swedish speakers with tertiary level education has been higher than that of Finnish speakers.

People born between 1956 and 1960 entered the school system before the education reform, whereas those born between 1961 and 1965 and between 1966 and 1970 entered after it. From the table, we can see that there has been a dramatic increase in the proportion of people with upper secondary education, especially among men.

The number of individuals with tertiary level education has not increased. This is an artefact of the large increase in the number of people with upper secondary education in relation to the relatively smaller increase of available tertiary-level student places. As can be seen in the footnotes of the table, there is an overall increase in the proportion of the whole cohort with tertiary level education. These findings show the need to analyse the role of social background variables on education propensity. Logistic regression models are used to quantify the effects. Since the data constitute the whole population, significance testing in a traditional sense is not meaningful. Yet ordinary tests are used. We shall therefore study how well the models used fit the population under study by determining the independent impact of each variable. 


\section{Results}

We started our analysis of upper secondary education propensity by using main effects models, calculated separately for each gender and each language group. In order to depict potential cohort effects of the background variables, we also entered two-way interactions between cohort and each of the background variables. Most of the interactions significantly improved the models, which led us to the conclusion that it would be more appropriate to estimate separate models for each cohort. The results are presented in Table III.

From the table, we can see that there are strong but diminishing effects of social background on education propensity. Specifically, people from an upperlevel white-collar background have a substantially higher education propensity than those from a blue-collar background. As an example, the probability of having upper secondary education for a Finnish-speaking male born between 1966 and 1970 from a blue-collar background who lives with both parents in the Helsinki area is 0.395 . The corresponding probability for a person from an upper-level white-collar background is $0.767 .^{5}$ For women, the impact of socio-economic background is somewhat less strong. The inter-cohort changes in these effects are also smaller for women than for men.

Family background is also very important. Education propensity for those living with only one or no parent is substantially lower than for those raised in two-parent families. The probability of having upper secondary education for a person with the same characteristics as above (blue-collar background), except for one-parent background, is $0.288 .{ }^{6}$ There is no clear cohort effect for the family background variable.

There are evidently some regional differences. As expected, education propensity is higher in urban than in rural areas. Between-region differences seem to have diminished in the youngest cohort. Hence, the education reform has not had an immediate impact on education propensity. Yet there also remain substantial differences in that cohort, except for Finnish-speaking females.

For Swedish speakers, education propensity is highest in the Helsinki area. For Finnish speakers, the regional differences are smaller than for Swedish speakers.

The constant in each model gives the general level of education propensity. We can see that education propensity is higher for Swedish speakers than for Finnish speakers in the Helsinki area. A similar pattern is found for the Turku area, whereas there are practically no language-group differences in other urban areas, nor in rural areas. We interpret this as an indication that, with regard to education traditions, the Swedish-speaking population in the Helsinki and Turku areas is different from Swedish speakers living in other parts of the bilingual area.

An important conclusion of our analysis is that there are striking similarities between Swedish and Finnish speakers with regard to the effect of socio-economic and family background on education propensity. Considering that the two language groups follow the similar basic structure of the education system, this is perhaps not very surprising. As such, these findings support the important role of social background on education. The negative impact of a farmer background on upper secondary education propensity for Swedish-speaking men in the youngest cohort may be due to traditionally strong 'ties to the land'.

The overall education propensity of women is higher than that of men. Yet differences between genders in the effect of background variables are very small. 


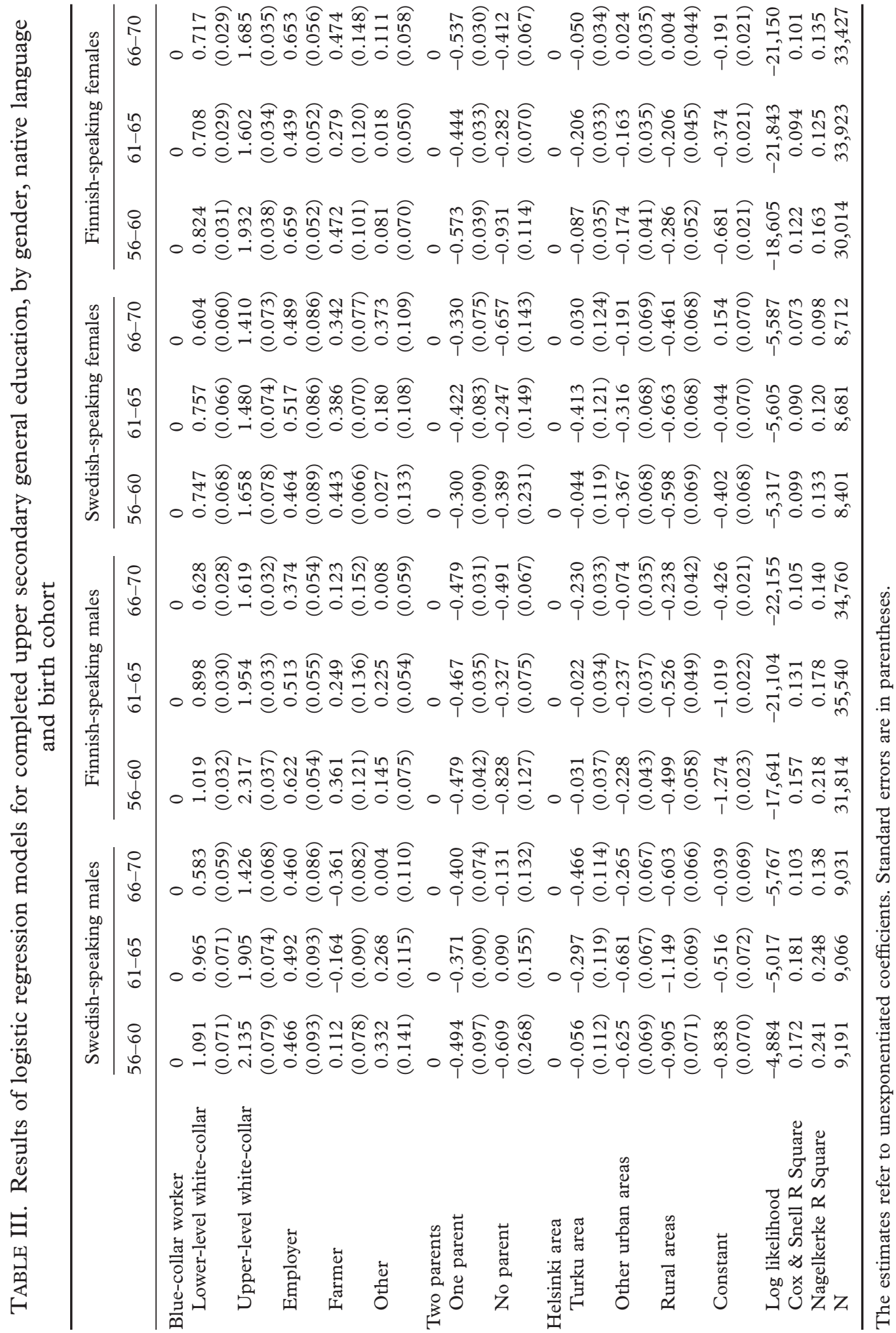


For completed tertiary level education, we proceeded with the analysis in the same way as above. However, since there were no indications of inter-cohort changes in the effects of background variables on education propensity, we did not have to estimate different models for each cohort, nor include interaction terms between birth cohort and each background variable. Table IV is consequently for pooled birth cohorts, where a variable representing birth cohort is included to depict the overall inter-cohort change in education propensity.

TABLE IV. Results of logistic regression models for completed tertiary level education at age $25-29$ and at age 30-34 by gender and native language

\begin{tabular}{|c|c|c|c|c|c|c|c|c|}
\hline & \multicolumn{4}{|c|}{ AT AGE 25-29 } & \multicolumn{4}{|c|}{ AT AGE 30-34 } \\
\hline & \multicolumn{2}{|c|}{ Males } & \multicolumn{2}{|c|}{ Females } & \multicolumn{2}{|c|}{ Males } & \multicolumn{2}{|c|}{ Females } \\
\hline & Swedish & Finnish & Swedish & Finnish & Swedish & Finnish & Swedish & Finnish \\
\hline 1956-1960 & 0 & 0 & 0 & 0 & 0 & 0 & 0 & 0 \\
\hline 1961-1965 & $\begin{array}{l}-0.157 \\
(0.059)\end{array}$ & $\begin{array}{c}-0.311 \\
(0.033)\end{array}$ & $\begin{array}{c}0.042 \\
(0.053)\end{array}$ & $\begin{array}{l}-0.295 \\
(0.032)\end{array}$ & $\begin{array}{l}-0.054 \\
(0.055)\end{array}$ & $\begin{array}{c}-0.212 \\
(0.028)\end{array}$ & $\begin{array}{c}0.153 \\
(0.051)\end{array}$ & $\begin{array}{l}-0.184 \\
(0.028)\end{array}$ \\
\hline $1966-1970$ & $\begin{array}{l}-0.091 \\
(0.055)\end{array}$ & $\begin{array}{l}-0.163 \\
(0.031)\end{array}$ & $\begin{array}{c}0.117 \\
(0.051)\end{array}$ & $\begin{array}{l}-0.042 \\
(0.030)\end{array}$ & $\begin{array}{l}\text { n.a. } \\
\text { n.a. }\end{array}$ & $\begin{array}{l}\text { n.a. } \\
\text { n.a. }\end{array}$ & $\begin{array}{l}\text { n.a. } \\
\text { n.a. }\end{array}$ & $\begin{array}{l}\text { n.a. } \\
\text { n.a. }\end{array}$ \\
\hline Blue-collar worker & 0 & 0 & 0 & 0 & 0 & 0 & 0 & 0 \\
\hline $\begin{array}{l}\text { Lower-level } \\
\text { white-collar }\end{array}$ & $\begin{array}{c}0.358 \\
(0.072)\end{array}$ & $\begin{array}{c}0.344 \\
(0.037)\end{array}$ & $\begin{array}{c}0.262 \\
(0.064)\end{array}$ & $\begin{array}{c}0.405 \\
(0.037)\end{array}$ & $\begin{array}{c}0.284 \\
(0.088)\end{array}$ & $\begin{array}{c}0.319 \\
(0.040)\end{array}$ & $\begin{array}{c}0.339 \\
(0.079)\end{array}$ & $\begin{array}{c}0.438 \\
(0.040)\end{array}$ \\
\hline $\begin{array}{l}\text { Upper-level } \\
\text { white-collar }\end{array}$ & $\begin{array}{c}0.768 \\
(0.069)\end{array}$ & $\begin{array}{c}0.884 \\
(0.034)\end{array}$ & $\begin{array}{l}0.723 \\
(0.061)\end{array}$ & $\begin{array}{c}1.142 \\
(0.033)\end{array}$ & $\begin{array}{c}0.897 \\
(0.084)\end{array}$ & $\begin{array}{l}1.008 \\
(0.037)\end{array}$ & $\begin{array}{c}0.974 \\
(0.076)\end{array}$ & $\begin{array}{c}1.331 \\
(0.036)\end{array}$ \\
\hline Employer & $\begin{array}{l}-0.011 \\
(0.106)\end{array}$ & $\begin{array}{c}0.183 \\
(0.069)\end{array}$ & $\begin{array}{l}0.336 \\
(0.085)\end{array}$ & $\begin{array}{c}0.402 \\
(0.062)\end{array}$ & $\begin{array}{l}-0.209 \\
(0.126)\end{array}$ & $\begin{array}{c}0.135 \\
(0.073)\end{array}$ & $\begin{array}{c}0.477 \\
(0.103)\end{array}$ & $\begin{array}{c}0.459 \\
(0.066)\end{array}$ \\
\hline Farmer & $\begin{array}{c}0.385 \\
(0.098)\end{array}$ & $\begin{array}{c}0.373 \\
(0.164)\end{array}$ & $\begin{array}{l}0.268 \\
(0.075)\end{array}$ & $\begin{array}{c}0.557 \\
(0.134)\end{array}$ & $\begin{array}{c}0.188 \\
(0.114)\end{array}$ & $\begin{array}{c}0.304 \\
(0.171)\end{array}$ & $\begin{array}{c}0.064 \\
(0.089)\end{array}$ & $\begin{array}{c}0.646 \\
(0.138)\end{array}$ \\
\hline Other & $\begin{array}{c}0.297 \\
(0.138)\end{array}$ & $\begin{array}{c}0.471 \\
(0.077)\end{array}$ & $\begin{array}{c}0.282 \\
(0.119)\end{array}$ & $\begin{array}{c}0.448 \\
(0.076)\end{array}$ & $\begin{array}{c}0.363 \\
(0.164)\end{array}$ & $\begin{array}{c}0.330 \\
(0.084)\end{array}$ & $\begin{array}{c}0.231 \\
(0.149)\end{array}$ & $\begin{array}{c}0.479 \\
(0.081)\end{array}$ \\
\hline Two parents & 0 & 0 & 0 & 0 & 0 & 0 & 0 & 0 \\
\hline One parent & $\begin{array}{c}-0.177 \\
(0.089)\end{array}$ & $\begin{array}{c}-0.189 \\
(0.043)\end{array}$ & $\begin{array}{l}-0.221 \\
(0.081)\end{array}$ & $\begin{array}{c}-0.234 \\
(0.042)\end{array}$ & $\begin{array}{c}-0.263 \\
(0.113)\end{array}$ & $\begin{array}{c}-0.019 \\
(0.048)\end{array}$ & $\begin{array}{c}-0.022 \\
(0.100)\end{array}$ & $\begin{array}{l}-0.108 \\
(0.048)\end{array}$ \\
\hline No family & $\begin{array}{l}-0.205 \\
(0.178)\end{array}$ & $\begin{array}{l}-0.266 \\
(0.102)\end{array}$ & $\begin{array}{c}-0.102 \\
(0.166)\end{array}$ & $\begin{array}{l}-0.332 \\
(0.103)\end{array}$ & $\begin{array}{c}-0.049 \\
(0.228)\end{array}$ & $\begin{array}{c}-0.174 \\
(0.125)\end{array}$ & $\begin{array}{c}0.043 \\
(0.214)\end{array}$ & $\begin{array}{l}-0.148 \\
(0.121)\end{array}$ \\
\hline Helsinki area & 0 & 0 & 0 & 0 & 0 & 0 & 0 & 0 \\
\hline Turku area & $\begin{array}{c}0.282 \\
(0.093)\end{array}$ & $\begin{array}{c}0.439 \\
(0.036)\end{array}$ & $\begin{array}{c}0.142 \\
(0.093)\end{array}$ & $\begin{array}{c}0.301 \\
(0.036)\end{array}$ & $\begin{array}{c}0.355 \\
(0.122)\end{array}$ & $\begin{array}{c}0.268 \\
(0.040)\end{array}$ & $\begin{array}{c}0.170 \\
(0.116)\end{array}$ & $\begin{array}{c}0.239 \\
(0.041)\end{array}$ \\
\hline $\begin{array}{l}\text { Other urban } \\
\text { areas }\end{array}$ & $\begin{array}{c}0.090 \\
(0.058)\end{array}$ & $\begin{array}{c}0.279 \\
(0.041)\end{array}$ & $\begin{array}{c}0.045 \\
(0.055)\end{array}$ & $\begin{array}{c}0.248 \\
(0.040)\end{array}$ & $\begin{array}{c}0.212 \\
(0.070)\end{array}$ & $\begin{array}{c}0.099 \\
(0.049)\end{array}$ & $\begin{array}{c}0.107 \\
(0.067)\end{array}$ & $\begin{array}{c}0.098 \\
(0.048)\end{array}$ \\
\hline Rural areas & $\begin{array}{c}0.019 \\
(0.063)\end{array}$ & $\begin{array}{c}0.148 \\
(0.056)\end{array}$ & $\begin{array}{l}-0.072 \\
(0.058)\end{array}$ & $\begin{array}{c}0.065 \\
(0.054)\end{array}$ & $\begin{array}{c}0.086 \\
(0.077)\end{array}$ & $\begin{array}{c}0.160 \\
(0.068)\end{array}$ & $\begin{array}{c}-0.079 \\
(0.072)\end{array}$ & $\begin{array}{l}-0.006 \\
(0.064)\end{array}$ \\
\hline Constant & $\begin{array}{l}-1.425 \\
(0.079)\end{array}$ & $\begin{array}{l}-1.790 \\
(0.036)\end{array}$ & $\begin{array}{l}-1.482 \\
(0.070)\end{array}$ & $\begin{array}{c}-2.102 \\
(0.034)\end{array}$ & $\begin{array}{l}-0.791 \\
(0.088)\end{array}$ & $\begin{array}{c}-1.068 \\
(0.035)\end{array}$ & $\begin{array}{c}-1.131 \\
(0.080)\end{array}$ & $\begin{array}{l}-1.589 \\
(0.034)\end{array}$ \\
\hline Log likelihood & $-5,999$ & $-19,908$ & $-7,351$ & $-21,139$ & $-3,820$ & $-14,777$ & $-4,639$ & $-15,600$ \\
\hline $\begin{array}{l}\text { Cox \& Snell R } \\
\text { Square }\end{array}$ & 0.019 & 0.025 & 0.016 & 0.034 & 0.036 & 0.041 & 0.037 & 0.056 \\
\hline $\begin{array}{l}\text { Nagelkerke R } \\
\text { Square }\end{array}$ & 0.028 & 0.040 & 0.023 & 0.056 & 0.049 & 0.057 & 0.051 & 0.082 \\
\hline $\mathrm{N}$ & 10,675 & 41,146 & 13,195 & 48,529 & 5,760 & 23,684 & 7,368 & 28,549 \\
\hline
\end{tabular}

The estimates refer to unexponentiated coefficients. Standard errors are in parentheses. 
As suggested in Table II, there has been an overall decrease in education propensity in the two younger cohorts, especially for those born between 1961 and 1965 . This can only to a limited extent be explained by a slower graduation rate because there is also a strong negative effect for education at age 30-34. The decrease should therefore be attributed to tighter competition for student places at universities and (or) a higher drop-out rate (Haven, 1999, pp. 63-65). ${ }^{7}$

The impact of socio-economic and family background variables are similar in pattern but, as expected, less strong than for upper secondary education. The relative importance of upper-level white-collar background is higher for education at age 30-34 than for education at age 25-29. This could be due to specific education choices or other individual factors, which induce a slower graduation rate for people who are 'better off'. The impact of other socio-economic categories is fairly similar between education at age 25-29 and at age 30-34.

With regard to regional differences, we can see that, especially for Finnishspeakers, tertiary level education propensity is substantially lower for those from the Helsinki area than for others. This may be explained by better labour market opportunities for the less educated, tighter competition for student places at universities, and less mobility with regard to starting university studies elsewhere (i.e. outside the metropolitan area). Thus, once rural youths have achieved upper secondary education, the propensity for tertiary level education is almost the same as for urban youths. We may also mention that, after some experiments with a more detailed classification of the regional background variable, there were some indications that, especially for Swedish-speakers, the propensity for tertiary level education is highest in the county of Pohjanmaa, i.e. the one with the youngest university tradition (the shaded area up to the left on the map in Figure 1).

Language-group differences in tertiary level education propensity are substantial. They do not, however, differ between regions to the same extent as was the case with upper secondary education. Instead, there is an overall advantage for Swedish speakers.

There is no systematic pattern for the inter-cohort change in tertiary level education propensity. The lowest education propensity is found in the oldest cohort for Swedish-speaking females and in the middle cohort for the others.

Tertiary level education propensity of men, conditional on upper secondary education, is higher than that of women. Differences between genders in the effect of background variables are, as before, very small.

\section{Conclusion}

Our empirical analysis has shown that there is a strong impact of socio-economic and family background on education propensity. As expected, there are declining background effects from upper secondary education to tertiary level education. It is thus evident that educational selection mainly takes place at upper secondary level.

For upper secondary education, there are indications that the impact of social background has decreased over cohorts. This could be attributed to the education reform in the 1970 s, which aimed at increasing equality of educational opportunity. Yet the important role of social background on education has not disappeared.

The impact of socio-economic and family background is very similar between Swedish speakers and Finnish speakers. Considering that both follow a similar 
basic educational structure, this is to be expected. But there is some evidence that Swedish and Finnish speakers have different lifestyles. Swedish speakers experience greater marital stability, lower unemployment rates, better health, and a higher life expectancy than Finnish speakers living in the same area (Finnäs, 1997; Saarela \& Finnäs, 2003; Hyyppä \& Mäki, 2001; Valkonen, 1982; Martelin, 1994). Hence, one would perhaps also expect some difference with regard to education behaviour, but this does not seem to be the case. In the Helsinki and Turku areas, Swedish speakers have a higher upper secondary education propensity. No such disparities can be found in the other urban and rural areas.

Swedish speakers are more likely to have completed tertiary level education. An obvious reason is that the number of student places is higher for them. It is, however, interesting to note that there seems to be language-group differences in the attitudes towards tertiary level education. We have used a supportive dataset that is part of the survey Kouluterveys (Health in Schools) carried out by the Finnish National Research and Development Centre for Welfare and Health (Stakes) to have a detailed picture of schoolchildren's health, lifestyles and working environment, but it also included questions about their plans for future education. The dataset we used represents all schoolchildren at eighth and ninth grade of elementary school in the province of Vaasa (the shaded and non-shaded parts of the large region on top of the map in Figure 1) in 1997. Based on this dataset, we could see that, when verifying a number of background variables such as the education level of the father, there was practically no language-group difference in intentions to begin upper secondary education. The language-group difference in odds for reporting intentions to start university studies turned out to be about $30 \%$. This may be compared with a language-group difference of about $32 \%$ in tertiary level education propensity for males, and $58 \%$ for females, calculated for the reference individual in the present data. ${ }^{8}$ It is thus fairly evident that Swedish speakers seem to be more motivated to begin tertiary level studies. This could be because they know that it is relatively easy for them to obtain a student place.

Finally, it should be stressed that we have only been concerned with completed education, not with admission selections or drop-outs. Since the competition for tertiary level education places is tighter for Finnish speakers than for Swedish speakers, one could argue that the quality of the output (i.e. of those completing education) is higher amongst the former.

\section{Acknowledgement}

Financial support from Stiftelsen för Österbottens Högskola is gratefully acknowledged.

\section{NOTES}

1. The effect may be regarded as indirect, working through mental ability, grades and financial factors, as well as through the selective influences of peers, parents and teachers (Nam \& Folger, 1965; Mare, 1980).

2. A municipality is classified as bilingual if the minority exceeds $8 \%$ or 3,000 inhabitants. 
3. People whose native language is neither Finnish nor Swedish are not included $(0.2 \%$ of the population). Those who are lost between censuses, due to death or emigration, are also excluded ( $4.0 \%$ of the population).

4. Analysing both language groups or both genders together will result in spurious estimates for the effects of the background variables.

5. $0.395=1 /(1+\exp -[-0.426])$ and $0.767=1 /(1+\exp -[-0.426+1.619])$.

6. $0.288=1 /(1+\exp -[-0.426-0.479])$.

7. The negative effect for cohort 1961-1965, for education at age 25-29, remained also when we tried to exclude cohort 1966-1970 from the estimations. The present results cannot therefore be attributed to birth-cohort differences in the composition of background variables.

8. For completed tertiary level education at age 30-34, according to Table IV: $\exp (-0.791) / \exp (-1.068)=1.320$ for males and $\exp (-1.131) / \exp (-1.589)=$ 1.581 for females.

\section{REFERENCES}

Central Statistical Office of Finland (1988) Pojat ja Tytöt Koulussa 1987 [Boys and Girls at School 1987] Education and Research, no. 7 (Helsinki, Central Statistical Office of Finland) (in Finnish, English summary).

Corcoran, M., JENCKs, C. \& OlnECK, M. (1976) The effects of family background on earnings, American Economic Review, 66, pp. 430-435.

Corcoran, M., Gordon, R., LAREN, D. \& Solon, G. (1990) Effects of family and community background on economic status, American Economic Review, 80, pp. 362-366.

FINNÄS, F. (1997) Social integration, heterogeneity, and divorce: the case of the Swedish-speaking population in Finland, Acta Sociologica, 40, pp. 263-277.

FINNÄS, F. (2001) Finlandssvenskarna inför 2000-talet — En Statistisk Översikt (The Swedish-speakers in the 21st Century - A Statistical Overview. Finlandssvensk Rapport, No. 40 (Helsinki, Svenska Finlands Folkting)(in Swedish).

HAuser, R. M. \& SEwell, W. H. (1986) Family effects in simple models of education, occupational status, and earnings: findings from the Wisconsin and Kalamazoo studies. Fournal of Labor Economics, 4, S83-S115.

HaVEN, H. (Ed) (1999) Education in Finland 1999. Education, No. 4. (Helsinki, Statistics Finland).

НYYPPÄ, M. T. \& MÄKI, J. (2001) Why do Swedish-speaking Finns have a longer active life? An area for social capital research, Health Promotion International, 16, pp. 55-64.

KIVINEN, O. (1988) Koulutuksen Färjestelmäkehitys. Peruskoulutus ja Valtiollinen Kouludoktriini Suomessa 1800- ja 1900-luvulla (The Systematisation of Education. Basic Education and the State School Doctrine in Finland in the 19th and 20th Centuries). Doctoral Dissertation. Annales Universitatis Turkuensis, Series C, No. 67 (Turku, Turun Yliopisto) (in Finnish, English Summary).

KIVINEN, O. (1996) Higher education, mobility and inequality: the Finnish case, European Fournal of Education, 31, pp. 289-310. 
KIVINEN, O. \& RINNE, R. (1996) The Social Inheritance of Education. Equality of Educational Opportunity among the Young People in Finland (Helsinki, Statistics Finland).

Kivinen, O., IsOAHO, H. \& RinNe, R. (1990) Education and Social Background of the Young in Finland. Studies, No. 172. (Helsinki, Central Statistical Office of Finland).

LAMPINEN, O. (1998) Suomen Koulutusjärjestelmän Kehitys (Development of the Finnish Education System) (Tampere, Gaudeamus) (in Finnish).

MARE, R. M. (1979) Social background composition and educational growth, Demography, 16, pp. 55-71.

MARE, R. M. (1980) Social background and school continuation decisions, Fournal of the American Statistical Association, 75, pp. 295-305.

Martelin, T. (1994) Differential Mortality at Older Ages. Doctoral Dissertation (Publications of the Finnish Demographic Society, No. 16) (Helsinki, Demographic Society).

NAM, C. B. \& Folger, J. K. (1965) Factors related to school retention, Demography, 2, pp. 456-462.

RANTA, H. (Ed) (1998) Opetustoimen Lainsäädäntö 1999 [Educational Legislation 1999]. Lakimiesliiton Kustannus. Kauppakaari Oyi, Juva (in Finnish).

SAARELA, J. \& FINNÄS, F. (2002) Unemployment and native language: the Finnish case, fournal of Socio-Economics.

SEwell, W. H. \& Hauser, R. M. (1975) Education, Occupation, and Earnings: achievement in the early career (New York, Academic Press).

STATISTICS FINLAND (1991) Väestölaskentojen Pitkittäistiedosto 1970-1985. Käsikirja (The Finnish Longitudinal Census Data File 1970-1985. Manual) (Helsinki, Statistics Finland) (in Finnish).

STATISTICS FINLAND (1993) Korkeakouluihin Hakeneet ja Hyväksytyt 1993 (University Applications and Intake in 1993). Education, No. 9 (Helsinki, Statistics Finland) (in Finnish).

VAlkonen, T. (1982) Psychosocial stress and sociodemographic differentials in mortality from ischeamic heart disease in Finland, Acta Medica Scandinavica, 660, pp. 152-164. 